\title{
WHAT CAN AND SHOULD BE LEGALIZED IN ECOLOGICAL RESTORATION? ${ }^{1}$
}

\author{
James Aronson ${ }^{2}$
}

\begin{abstract}
After listing the five key elements of ecological restoration, ecology, economics, social values, cultural values, and politics, I celebrate the fact that in Brazil there is legislation on how to perform ecological restoration of degraded tropical forests, as well as an ongoing dialogue among legislators and scientists about this legislation, and also a lively debate among scientists as the best way forward, referring to articles by Brancalion et al. (2010) and Durigan et al. (2010) in this issue of Revista Árvore. Legislators elsewhere, especially megadiversity countries, should take note. I do not take sides in the debate; I think both groups of authors make very good points. Instead I call on the scientists and legislators concerned with restoration to ponder five strategic tools: A. Start with clear concepts. B. Decide where you want to go and why. C. Negotiate who should benefit \& how, and who should pay, how, \& why. D. Work out how an honest cost-benefit analysis of restoration would look, regardless of the biome in which you are working. Finally, figure out how to make the restoration immediately attractive for private landowners. Otherwise, they will not cooperate as fully as they could or should, and restoration efforts will not achieve its full potential.
\end{abstract}

Keywords: legal instruments, restoration decision making and restoration cost-effectiveness.

\section{O QUE PODE E DEVERIA SER LEGALIZADO NA RESTAURAÇÃO ECOLÓGICA?}

\begin{abstract}
RESUMO - Depois de listar os cinco elementos chave da restauração ecológica - ecologia, economia, valores sociais, valores culturais e política, eu celebro o fato de que no Brasil há uma legislação sobre como conduzir a restauração ecológica de florestas tropicais degradadas, bem como o diálogo em andamento entre legisladores e cientistas sobre essa legislação, e também o intenso debate entre cientistas sobre a melhor forma de avançar, referindo aos artigos de Brancalion et al. (2010) e Durigan et al. (2010) nessa edição da Revista Árvore. Legisladores de todas as regiões, especialmente de países de megadiversidade, devem tomar nota. Eu não tomei partido por um dos lados no debate; eu acredito que ambos os grupos de autores apresentaram pontos muito bons. Em vez disso, eu sugiro que os cientistas e legisladores ponderem cinco ferramentas estratégicas: A. comece com conceitos claros. B. analise onde se quer chegar e por que. C. Negocie quem deveria se beneficiar e como, e quem deveria pagar, como e por que. D. Exercite uma análise honesta de custo-benefício da restauração, independentemente do bioma onde se está trabalhando. Finalmente, analise como tornar a restauração atrativa de imediato para os proprietários rurais. Caso contrário, eles não vão cooperar efetivamente da forma como eles poderiam ou deveriam, e os esforços da restauração não irão alcançar seu potencial por completo.

Palavras-chave: Instrumentos legais, tomada de decisão na restauração e custo-benefício da restauração.
\end{abstract}

At the time of this writing, I am still reeling from the debacle of the meetings of the CITES convention held in March 2010. No new protection was accorded to whales, sharks or even the red tuna, all of which are nearly over the tipping point to extinction. There was nothing there for the giant denizens of the oceans, except a de facto call for more business as usual, which in this case means more industrial killing of whales, and more short-sighted “mining” of large predators that also happen to be valuable resources providing protein for people, of course, and above all much profit for some few people, at the expense of future generations of people, and the ecosystems of the oceans.

The role of government is to protect the general or the common interest of a nation, including that of future generations. In that light, all nations need to be investing much more heavily in restoration, recuperation and

\footnotetext{
${ }^{1}$ Recebido em 09.12.2009 e aceito para publicação em 02.03.2010.

${ }^{2}$ Centre d'Ecologie Fonctionnelle et Evolutive (CNRS-UMR 5175), 1919, Route de Mende, 34293, Montpellier France, and Missouri Botanical Garden, USA. E-mail: <james.aronson@cefe.cnrs.fr>.
} 
replenishment of our limited supplies of renewable natural capital, ie. biodiversity and well-functioning ecosystems - maritime, aquatic and, of course, terrestrial (CAIRNS, 1993; ARONSON et al., 2007).

In a famous figure of Jackson et al. (1995), that expressed the viewpoint of the executive board of the SER (Society forEcological Restoration International; www.ser.org), ecological restoration was portrayed as having 4 main components to consider - ecological, social, cultural and economic. In 2010, especially thanks to the pioneering legislation of the state of São Paulo, we can see that there is one more element, namely the political. The figure should look like that shown in Figure 1.

National and regional governments, thus, have a big role to play in ecological restoration in the coming years, and this is a relatively new idea. The EU and many individual countries elsewhere have laws on the books about conservation, but not restoration... Brazil is one of very few countries in the world - along with Australia, Japan, Canada, the USA, and South Africa - where some kind of public policy and detailed legislation exists to promote, reward or enforce restoration of degraded ecosystems.

All too often, the restoration laws are confused, and allow compensation, or mere cleaning-up afterwards, instead of demanding and imposing true restoration. Governments should decide who will pay for restoration? And who should benefit? In the future, markets may decide, but not for a long time. Judging from the dismal success of carbon markets to achieve anything significant, I argue that for now, it is up to far-sighted governments.

Source: Modified from JACKSON et al., 1995. Fonte: Modificado de JACKSON et al. 1995.

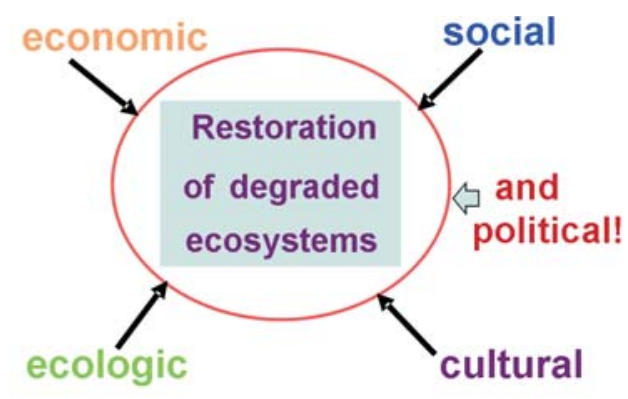

Figure 1 - The five elements of ecological restoration. Figura 1 - Os cinco elementos da restauração ecológica.
There is a need and a place for government decrees, and legal instruments, to determine when, where and how to perform restoration. As to when and where the issue is really whether after-the-fact compensatory measures should be considered sufficient, in a spirit of "no net loss". I think not. Terrible compromises may arise, and falsehoods, as we have seen in the USA (see discussion of technocratic motivations for restoration, in CLEWELL and ARONSON 2006, 2007) and in various debates now underway in the European Union. As to HOW to restore, that brings us back to Brazil, and the subject of the two excellent essays that precede this one, by Brancalion et al. (2010), and Durigan et al. (2010).

Brazil is perhaps the only country where legislation is in effect on the way in which it should be done. Not surprisingly, for something so new, much controversy exists within the academic and professional community in Brazil, not only about what should be the best practice for a given ecosystem or ecosystem type, e.g. tropical rainforest in the Mata Atlantica. This is not surprising for three reasons: 1) so little is known about how to successfully restore a badly degraded, and fragmented tropical forest; 2) much controversy still exists around the world about basic concepts like what ecological restoration really means and what it can do; and 3) Brazil - or more specifically the state of Sao Paulo, is, apparently, the first in the world to attempt legislation on how to conduct restoration, so there are no models elsewhere. This means that what is being discussed here is of truly global importance, and may go down in the annals of restoration history.

Both financial and non-financial drivers for ecological restoration exist (see chapters 32 and 33 in ARONSON et al., 2007, as well as NEßHÖVER et al., in press). But not nearly enough is being done. We need a thousand times more to be done, and quickly....Therefore, it is clear that legal instruments can help, but they can be inconvenient burdens for some. If the objective is to promote investment in restoration - both the science and practice in an overwhelmingly capitalist world - then we need legal instruments. However, they must be effective, and supple, and yet they must not restrain innovation and adaptation. They must also be accompanied by fiscal incentives to encourage voluntary investments, and not just penalties for landowners and companies that fail to comply. In other words, both Brancalion et al. (2010) and Durigan et al. (2010), are right! 
How to arbitrate or mediate this debate? I don't pretend to know the answer. All I wish to say to all concerned, and to the legislators, is as follows:

- Start with clear concepts.

- Decide where you want to go and WHY.

- Negotiate who should benefit \& how, and who should pay, how, \& why.

- Figure out how an honest cost-benefit analysis of restoration would look, which means distinguishing between market and non-market values, and including them all.

Once there are answers to these questions - political, and economic, in nature, and based also on environmental and intergenerational ethics, that should help forward in the transition towards sustainability, for which ecological restoration has such a large role to play. But, beware of straightjackets! As Durigan et al. (2010) remind us, there is no one-size-fits-all recipe for ecorestoration. Brancalion et al. (2010) obviously know this simple truth as well, but the politicians and land owners need to remember too. In the western part of the state of Sao Paulo, for example, there are very few forest remnants left, and they are very widely scattered. Most of the territory has been replaced by industrial or small-scale agriculture, as well as exotic tree plantations that have obvious short-term benefits but may be causing long-term damage. In this context, there may be little spontaneous reinvasion of native species, according to Brancalion et al., in which case a lot of intentional work needs to be done. Or, there may be a considerable amount of autogenic restoration, according to Durigan et al. (2010). No one knows as yet. Experiments are needed to determine what's needed? What's the best practice? What's the most effective?

Should the state of São Paulo require a minimum number of "framework" or foundation species, as suggested by Brancalion et al. (2010), or else eliminate the minimum number as suggested by Durigan et al. (2010)? Pilot scale experiments are needed, in my view, to settle this issue, and part of the public policy should be to call for, and fund such experiments! An additional consideration to be discussed in this regard is the notion of reference ecosystems to orient a restoration project.
This powerful concept is used by some - but not all - restoration scientists and practitioners around the world and would seem highly applicable in the Mata Átlantica biome. However, the alternative approach - restoring processes - is also powerful. Biodiversity and ecosystem services are shared goals in these two approaches, of course. But many other details and nuances can and should be considered, from all five of the angles highlighted in Figure 1, above. In practice, much depends on the objectives of the project and the overarching program, and legislation.

If I may be allowed one more comment, I would note that neither article pays much attention to the thorny problem of the economic interest for land owners on private land, and for the state, on public land. This may be the limiting factor, and it is certainly an additional issue for legislators to address, along with the important question of whether or not there should be a minimum number of native species present in the restored area or not.

For most land owners in the Mata Atlântica biome, small and large alike, the biggest issue of all is probably whether or not they can cut trees in a protected or restored area, and thereby recoup some of their economic costs, and/or amortize some of their opportunity costs. They are being asked to forego short-term private profit in the general interest, and in the interest of their children. If they don't have social, cultural and ecological motivations to do so, they need political, and then, economic drivers to help them along the way.

Finally, bravo to all the authors who contributed to the two previous papers. Only a small minority (ca. 8\%), of the scientists and practitioners who published work on ecological restoration in 13 peerreviewed international journals between 2000 and 2008 discussed links between the ecological restoration and payments for ecosystem services (ARONSON et al., 2010) and less than 10\% of the papers surveyed in that study mentioned possible policy implications for their work in restoration. Happily, it seems that this trend is likely to be reversed in the coming years (e.g., GOLDSTEIN et al., 2009; REY BENAYAS et al., 2009).

I hope this trilogy to which I am delighted to contribute will also be published in revised form, in one of the two journals of SER International, so that the growing international community of restoration scientists, advisors, service-providers, decision-makers, and of course practitioners, can learn from it and nourish their own national, regional, and local debates.

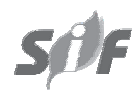

Revista Árvore, Viçosa-MG, v.34, n.3, p.451-454, 2010 


\section{REFERENCES}

ARONSON, J.; MILTON, S.J.; J. BLIGNAUT, J. Eds. Restoring natural capital: science, business and practice. Washington, D.C.: Island Press, 2007.

ARONSON, J. et al. Are socio-economic benefits of restoration adequately quantified? A metaanalysis of recent papers (2000-2008) in restoration ecology and 12 other scientific journals. Restoration Ecology, v.18, p.143-154, 2010.

BRANCALION, P.H.S. et al. Instrumentos legais podem contribuir para a restauração de florestas tropicais biodiversas. Revista Árvore, v.34, n.3, p.455-470, 2010.

CAIRNS, J.Jr. 1993. Ecological restoration: Replenishing our national and global ecological capital. In: SAUNDERS, D.; HOBBS, R.;

EHRLICH, P. (Eds.). Nature conservation 3: reconstruction of fragmented ecosystems. Chipping Norton, NSW, Australia: Surrey Beatty and Sons, 1993. p.193-208.

CLEWELL, A.F.; ARONSON, J. Motivations for the restoration of ecosystems. Conservation Biology, v.20, p.420-428, 2006.

CLEWELL, A.F.; ARONSON, J. Ecological restoration: principles, values, and structure of an emerging profession. Washington, D.C.: Island Press, 2007.
DURIGAN, G. et al. Normas jurídicas para a restauração ecológica: uma barreira a mais a dificultar o êxito das iniciativas? Revista Árvore, v.34, n.3, p.471-485, 2010

GOLDSTEIN, J. H.; PEJCHAR, L.; DAILY, G.C. Using return-on-investment to guide restoration: a case study from Hawaii. Conservation Letters, v.1, p.236-243, 2008.

JACKSON, L.L.; LOPOUKHINE, N.; HILLYARD, D. Ecological restoration: a definition and comments. Restoration Ecology, v.3, p.71-75, 1995.

MILLENNIUM ECOSYSTEM ASSESSMENT (MA). Ecosystems and human well-being synthesis. Washington, DC: Island Press, 2005.

NEßHÖVER, C. et al. Investing in ecological infrastructure. In: The economics of ecosystems and biodiversity in national and international policy making. An output of TEEB, edited by Patrick ten Brink. London: Earthscan, in press.

REY BENAYAS, J.M.; NEWTON, A.C.; BULLOCK, J.M. Enhancement of biodiversity and ecosystem services by ecological restoration: a metaanalysis. Science, v.325, p.1121-1124, 2009.

SOCIETY FOR ECOLOGICAL RESTORATION INTERNATIONAL (SER). Science and Policy Working Group. The SER International Primer on Ecological Restoration. 2004. www.ser.org. 